RAILROAD IMPACT IN BACKWARD ECONOMIES: SPAIN, 1850-1913.

\author{
Alfonso Herranz-Loncán (University of Barcelona) \\ Department of Economic History and Institutions \\ Faculty of Economics \\ Diagonal, 690 \\ 08034 Barcelona (Spain) \\ alfonso.herranz@ub.edu
}

I thank the financial support of the Bank of Spain and the Spanish Ministry of Education Grant SEJ2005-02498. I gratefully acknowledge comments by participants in seminars at the London School of Economics, UC-Berkeley, the Universities of Oxford, Barcelona, Valencia, Zaragoza, Carlos III and Pompeu Fabra, and at the $5^{\text {th }}$ European Historical Economics Society Conference (Madrid, July 2003). I am particularly indebted to Dudley Baines, Nicholas Crafts, Antonio Gómez Mendoza, Patrick O’Brien, Pere Pascual, Leandro Prados de la Escosura, Max-Stephan Schulze, Carles Sudrià, William Summerhill, Daniel A. Tirado and three anonymous referees. This implies no responsibility on their part for the shortcomings that may remain in the paper. 


\title{
RAILROAD IMPACT IN BACKWARD ECONOMIES: SPAIN, 1850-1913.
}

\begin{abstract}
This article reassesses the economic impact of Spanish railroads in 1850-1913, which has been usually considered to be substantially higher than in the most developed countries on the basis of the social saving methodology. The application of growth accounting techniques shows, by contrast, that the direct contribution of railroads to economic growth was lower in Spain than in the UK, mainly due to the low importance that railroad transport had within Spanish GDP before 1913.
\end{abstract}

Railroads constituted one of the most important technological breakthroughs of the nineteenth century, leading to a substantial upward shift in national economies' production functions worldwide. Attempts to measure their growth impact have given rise to one of the most famous debates in economic history, one of whose conclusions is the idea that their role was especially crucial in those countries which lacked an extensive system of waterways by the beginning of the railroad era, and/or whose geography put serious constraints on the development of water transport. ${ }^{1}$ The main empirical support of this hypothesis has come from the estimation of the social savings of railroads in different countries. The social saving technique, which was pioneered by Robert Fogel's research on the US case, aims at estimating the additional cost of transporting the railroad output of one year by the next best alternative means. This additional cost, which is usually expressed as a percentage of each country's gross domestic product, would be equivalent to the resource savings provided by the railroads to the economy, under the assumptions of a priceinelastic transport demand and absence of idle resources. ${ }^{2}$

As may be observed in Table 1, the first social saving estimates, which were produced for highly developed countries, such as the US or the UK, were rather small, because those economies had a relatively large endowment of waterways or good possibilities to resort to coastal trade by the beginning of the railroad era and, therefore, low prospects to reduce transport unit costs through the use of railroads. By contrast, when the same methodology was applied to less developed economies with fewer possibilities to resort to cheap water transport, such as Spain in Europe, or Mexico, Brazil and Argentina in the Americas, the ratios between each country's social savings and GDP turned out to be much higher. The main alleged reason for that situation was the prominence that roads

\footnotetext{
${ }^{1}$ See, among others, Fogel, Railroads, p. 31, and O'Brien, “Transport”, pp. 12-13.

${ }^{2}$ See Fogel, "Notes", pp. 2-5.
} 
would have had in a counterfactual transport system without railroads in those countries, which would have increased substantially the unit savings in transport costs that were produced by the railroad system.

TABLE 1
ESTIMATES OF SOCIAL SAVINGS (SS) ON FREIGHT TRANSPORTED BY
\begin{tabular}{lcc}
\multicolumn{3}{c}{ RAILROADS IN SEVERAL COUNTRIES } \\
\hline & Date & $\begin{array}{c}\text { SS expressed as } \\
\text { a share of GNP/GDP (\%) }\end{array}$ \\
\hline Belgium & 1846 & 1 \\
US & 1859 & 3.7 \\
US & 1890 & $4.7^{\mathrm{a}}$ \\
England and Wales & 1865 & 4.1 \\
Russia & 1907 & 4.5 \\
France & 1872 & 5.8 \\
Spain & 1878 & $3.9 / 6.4^{\mathrm{b}, \mathrm{c}}$ \\
Spain & 1912 & $18.9^{\mathrm{c}}$ \\
Brazil & 1913 & $18.0 / 38.0$ \\
Mexico & 1910 & $24.9 / 38.5$ \\
Argentina & 1913 & 26.0 \\
\hline
\end{tabular}

${ }^{\text {a }}$ Fogel's estimate for the US in 1890 is the only one to allow for improvements in alternative transport infrastructure in the absence of the railroads, which brings his percentage downwards relative to the others.

${ }^{\mathrm{b}}$ In the Spanish case, the first percentage for 1878 allows for the presence of idle resources in the economy, whereas the second ignores it.

${ }^{\mathrm{c}}$ Spanish percentages are expressed in terms of the most recent GDP estimates. In the case of 1878, they are much lower than suggested by Gómez Mendoza, "Spain" (6.4 instead of 11.9 percent), because this author expressed the social savings for that year in terms of Mulhall's estimate of Spanish national income, in Mulhall, Progress. That estimate, according to Prados de la Escosura, Comercio, p. 67, contained serious downward biases, which were made up for in further Mulhall's works.

Note: All estimates in the table assume a price-inelastic transport demand.

Sources: For Belgium, Laffut, "Belgium", p. 221; for the US in 1859, Fishlow, American Railroads, pp. 37 and 52; for the US in 1890, Fogel, Railroads, p. 223; for England and Wales, Hawke, Railways, p. 196; for Russia, Metzer, Economic Aspects, p. 50; for France, Caron, "France", p. 44; for Spain, Gómez Mendoza, "Railways" and Prados de la Escosura, El progreso; for Brazil, Summerhill, Order, p. 89; for Mexico, Coatsworth, "Indispensable Railroads", p. 952; and, for Argentina, Summerhill, "Profit", p. 31.

However, it is arguable to what extent such a general interpretation may be drawn from the direct comparison among a few social saving estimates that have been produced for rather distant points of time and, in fact, railroad historians have been reluctant to accept its implications for some countries. In the Spanish case, for instance, some researchers have indicated that the hypothesis that the railroads had a considerable impact on economic growth, which might be inferred from the observation of Antonio Gómez Mendoza's social saving estimates in Table 1, is in conflict with other evidence, such as the low utilization of the network or the railroad companies' constant financial problems. According to some historians, it is difficult to understand why the Spanish railroad 
companies were unable to capture a larger share of the exceedingly high social savings of the railroad system. In that context, some authors have tried to reconcile all that apparently contradictory evidence. ${ }^{3}$ However, other researchers have insisted that the low density of use of the lines and the companies' financial failure constitute powerful evidence that Spanish railroads were constructed ahead of demand, without paying any serious attention to real transport needs and, accordingly, have pointed out that the economic effects of the Spanish railroads might have been lower than suggested by the social saving literature. ${ }^{4}$

This paper aims at reassessing the economic impact of the Spanish railroads from a new perspective, in order to shed some light on the ongoing debate on the topic. Instead of relying on the traditional social saving methodology, this research is based on the application of growth accounting techniques, which constitute the most usual way to evaluate the economic growth implications of new technology, and have been recently used by Nicholas Crafts to analyze the contribution of steam technology (railroads included) to British labor productivity growth between 1760 and 1910. Growth accounting addresses the general question "how much did the new technology contribute to productivity growth?", rather than the more specific question "how much faster was productivity growth as a result of the introduction of the new technology?", which is the actual objective of social saving analysis. ${ }^{5}$ In this paper, growth accounting techniques are used to evaluate the direct contribution of the railroads to Spanish economic growth and, as a result of that valuation, a new interpretation of the economic impact of railroads in Spain is suggested, which might probably be extended to other countries, such as Mexico, Brazil and Argentina, which had both low prospects to resort to cheap water transport and relatively low levels of development during the railroad era.

The next section describes the growth accounting framework that has been used in this research and the main empirical problems that have arisen in the analysis of the Spanish case. As is described there, the most important obstacle to apply this methodology was the difficulty to get reliable figures of TFP growth in the Spanish transportation sector. The third and fourth section of the paper describe the two alternative strategies that have been used to sort out this problem, i.e.: i) the econometric estimation of a cost function for

\footnotetext{
${ }^{3}$ Keefer, for example, has indicated that the companies' low rates of return were the counterpart of high construction profits, because investors wanted to secure their returns earlier rather than later, due to the lack of credibility of the Spanish State regarding property rights. See Keefer, "Protection".

${ }^{4}$ See, especially, Tortella, Los orígenes, p. 169, and "Introducción", pp. 250-53.

${ }^{5}$ Crafts, "Steam", p. 340.
} 
the Spanish railroad system, and ii) the use of the information contained in the social saving estimates. On the basis of those two empirical analyses it has been possible to calculate the direct contribution of the railroads to Spanish economic growth, which is compared in the fifth section with Crafts' previous research on the British case. The last section concludes.

\section{THE GROWTH ACCOUNTING METHOD}

The most usual way to measure the global contribution of technological change to economic growth is the estimation of the so-called "Solow Residual", on the basis of a typical Cobb-Duglas production function and competitive assumptions. The "Solow residual" $(\triangle A / A)$ was originally interpreted as the TFP growth provided by new technology, and is estimated from the following expression:

$\Delta Y / Y=s_{K} \Delta K / K+s_{L} \Delta L / L+\Delta A / A$

where $Y$ is total output, $K$ denotes the services provided by the capital stock, $L$ is the total number of hours worked, and $s_{K}$ and $s_{L}$ are the factor income shares of labor and capital, respectively.

Some recent research on the contribution of information and communication technologies to economic growth has been based on a generalization of expression (1), which aims at incorporating the hypothesis of endogenous innovation and embodied technological change. Stephen D. Oliner and Daniel E. Sichel, for instance, apply a disaggregated version of equation (1), in which different types of capital and different components of TFP growth are distinguished. This allows them to measure the impact of ICT on productivity, both through disembodied TFP growth and through the embodied capital-deepening effect of investment in ICT. Therefore, they transform expression (1) into:

$\Delta Y / Y=s_{K o} \Delta K_{o} / K_{o}+s_{L} \Delta L / L+\gamma(\Delta A / A)_{o}+s_{K I C T} \Delta K_{I C T} / K_{I C T}+\varphi(\Delta A / A)_{I C T}$

where $Y$ is total output, $L$ is the total number of hours worked, $K_{I C T}$ and $K_{o}$ are the services provided by capital stock in ICT and in other sectors, respectively, $A$ is the TFP level in the sector indicated by the subscript (ICT and other), $s_{L}, s_{K I C T}$ and $s_{K o}$ are the factor income shares of labor, ICT capital and other capital, and $\varphi$ and $\gamma$ are the shares of ICT and other 
sectors' production in total output. Equation (2) may be modified in order to account for labor productivity growth:

$\Delta(Y / L) /(Y / L)=s_{K o} \Delta\left(K_{o} / L\right) /\left(K_{o} / L\right)+\gamma(\Delta A / A)_{o}+s_{K I C T} \Delta\left(K_{I C T} / L\right) /\left(K_{I C T} / L\right)+\varphi(\Delta A / A)_{I C T}$

The contribution of a new technology to labor productivity growth may be approached by the sum of the last two terms of equation (3). In fact, this would be a lower bound estimate of the real impact of the new technology, as there may be spillovers from the sector under consideration to the rest of the economy. Unfortunately, growth accounting studies usually fail to quantify indirect TFP spillovers, due to the measurement difficulties involved. ${ }^{6}$

Table 2 displays Craft's estimates of the contribution of the railroads to British labor productivity growth between 1830 and 1910, which are the result of the application of this measurement technique. As is usual in this kind of exercises, figures in the table exclude TFP spillovers. The main conclusion that may be drawn from Crafts' estimates is that the impact of railroads before 1850, although appreciable, did not transform the overall growth rate of the economy, due to the small size of the sector relative to GDP. Actually, their maximum contribution arrived in 1850-1870, when TFP growth achieved its highest rate and the railroad system was much larger. During those two decades, the railroads would have accounted for nearly 20 percent of British income per capita growth. The importance of the railroads would have decreased later on to much lower levels, as both the slowness of productivity growth in the sector and the low investment in the network made up for the higher share that the railroad output accounted for within the economy.

\footnotetext{
${ }^{6}$ See Oliner and Sichel, "Information Technology”, pp. 16-20, and Crafts, “Steam”, pp. 339-340.
} 
TABLE 2

RAILROADS' CONTRIBUTION TO GROWTH IN BRITAIN (1830-1910)

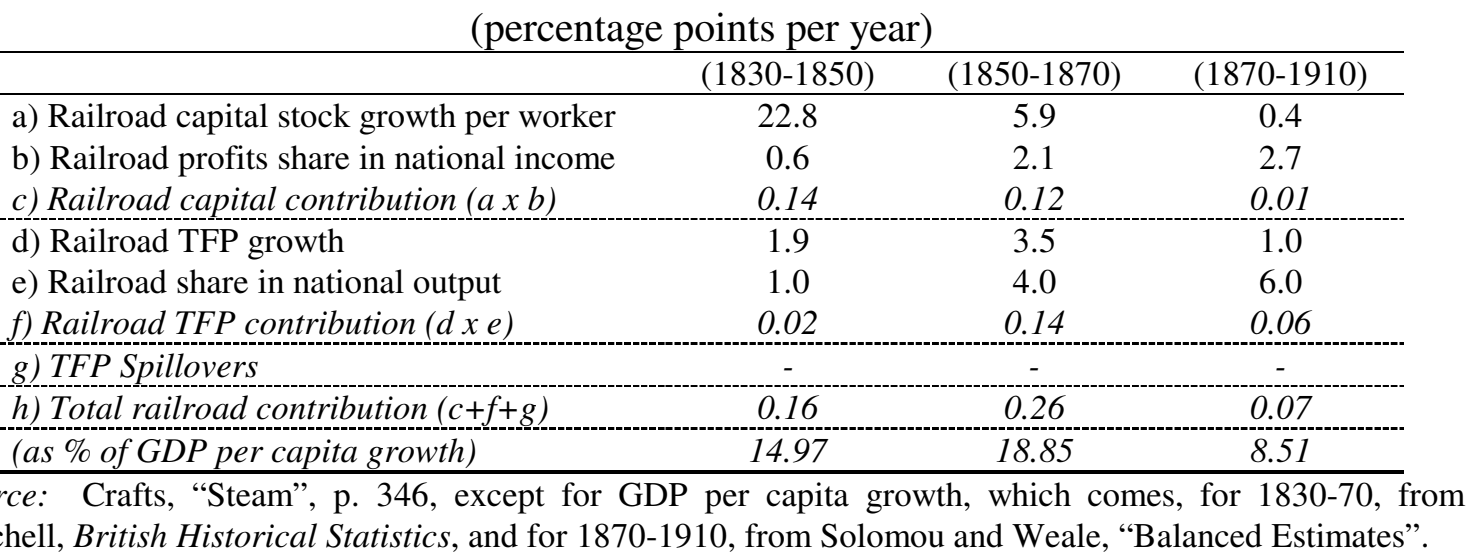

The application of this methodology to the Spanish railroads must face two main obstacles. The first one, which is shared with other research, is the difficulty to quantify TFP spillovers from the railroads to the rest of the economy. The relevance of spillovers is a non negligible potential source of downward bias in the estimation of the contribution of railroads to economic growth, whose absence must be kept in mind in the interpretation of the results. The second problem regards the estimation of the TFP term in expression (3). In his analysis of the British case, Crafts uses the available indices of TFP growth in the railroad sector, obtained through the application of conventional index number techniques. This procedure cannot be applied in the Spanish case, for two reasons. Firstly, there is not enough information available on some of the series that are necessary to directly estimate TFP growth indices in the Spanish railroads, such as the number of workers or the companies' yearly coal consumption. And, secondly, an index of TFP growth in the railroad sector cannot be assumed to include the whole TFP impact of Spanish railroads. Whereas the first British railroads had no great cost advantage over their main competitor (i.e. water transportation) when they were established, the first Spanish railroad services were considerably cheaper than the alternative modes they displaced (mainly traditional overland transportation). Therefore, an account of the whole TFP effects of the Spanish railroads should not only include TFP improvements within the railroad sector itself (as in Britain) but also those TFP gains that were associated with the shift from old forms of transportation to the railroads.

In this context, the TFP term in expression (3) may be approached in two steps. On the one hand, the rate of TFP growth within the railroad sector may be calculated on the 
basis of the econometric estimation of a cost function for the Spanish railroad companies. The basic form of such function is:

$C=C(Y, W, T, F)$

where $C$ is cost, $Y$ is the vector of outputs, $W$ is the vector of input prices, $T$ is time, and $F$ represents certain characteristics of each company's network, such as the average haul or load. The estimation of this function allows decomposing changes in railroad costs between its different sources: price variations (through the coefficients of $W$ ), growth of output (through the coefficients of $Y$ ), technical and organizational progress (through the coefficient of $T$ ) and changes in network characteristics. On the basis of the dual theory of production, the estimation of this function also allows calculating the growth rate of TFP in the Spanish railroads as the equiproportionate yearly increase in output with input fixed.

The growth rates of TFP obtained in this way may be compared with the British equivalent figures to analyze differences in productivity growth between both railroad systems. However, as has been indicated, they would not account for the whole TFP impact of the Spanish railroads, because they would exclude the TFP gains resulting from the substitution among different transport modes. These might be approached instead on the basis of the available social saving estimates for the Spanish railroad system. Social savings are usually calculated as:

$S S=\left(P_{A L T}-P_{F C}\right) \times Q_{F C}$

where $P_{F C}$ and $P_{A L T}$ are, respectively, the price of railroad and counterfactual transport, and $Q_{F C}$ is the railroad transport output in the reference year. This expression was interpreted by Fogel as a measure of the resources released by the railroad technology. ${ }^{7}$ It is actually an upward biased estimate (due to the assumption of a price-inelastic transport demand) of the equivalent variation consumer surplus which, if perfect competition in the rest of the economy is assumed, provides a general equilibrium measure of the entire direct real income gain obtained from reducing resource cost in transportation. ${ }^{8}$

As Crafts has recently stressed, the price dual measure of TFP allows considering such gain in real income as equivalent to the increase in TFP provided by the railroads. In a country like Britain, where railroads were only introduced at the point where they could

\footnotetext{
${ }^{7}$ Fogel, "Notes", p. 5.

${ }^{8}$ Metzer, "Railroads", p. 68; Jara-Díaz, "Relation".
} 
offer transport at the same cost as water transportation, it should actually be equivalent to TFP gains in the railroad sector itself. ${ }^{9}$ By contrast, in Spain, the social savings would not only reflect TFP growth in the railroad sector but also those TFP gains associated with the shift from old forms of transportation to the railroads. As a consequence, estimates of TFP increases based on the Spanish social savings might be compared with the British figures in order to analyze differences in the whole TFP growth impact of the railroad system (including the substitution among different transport modes). ${ }^{10}$ The next two sections present alternative figures of TFP gains, obtained through the estimation of a railroad cost function and through the use of the information contained in the social savings. These figures will be used in the last section to compare the economic impact of railroads in both countries.

\section{SPANISH RAILROAD TFP GROWTH: THE COST FUNCTION APPROACH}

There is a well-established tradition of using cost function analysis to estimate the structure of railroad production and the rate of growth of TFP in railroad systems. ${ }^{11}$ TFP growth is usually defined as the rate at which output can grow over time with inputs held constant $\left(\varepsilon_{y t}\right)$. In a sector as the railroads, with multiple outputs $\left(\mathrm{Y}_{1}, \mathrm{Y}_{2}, \ldots \mathrm{Y}_{\mathrm{n}}\right)$, the natural generalization is to define TFP growth as the common rate at which all outputs can grow over time with inputs held fixed. In terms of the derivatives of the total cost function (expression 4), dual to the production function, this means:

TFP growth $=\varepsilon_{y t}=-\varepsilon_{c t} \cdot\left(\Sigma \varepsilon_{c y i}\right)^{-1}$

This is equivalent to estimate TFP growth as the product of two factors: the rate of growth of technical change (i.e. the rate at which all inputs can be decreased over time with outputs held fixed; $-\mathcal{E}_{c t}$ in expression 6), and the level of returns to scale in the system (i.e. the proportional increase in all outputs that results from a proportional increase in all inputs with time fixed; $\left(\Sigma \varepsilon_{c y i}\right)^{-1}$ in expression 6).

\footnotetext{
${ }^{9}$ Crafts, "Social savings", p. 6.

${ }^{10}$ Actually, although small, there was also some potential transport cost reduction in Britain coming from the substitution of the railroads for alternative transport modes; see Hawke, Railways. Therefore, an account of the growth contribution of the British railroads such as that in Table 2, which is just based on the increase in TFP within the railroad sector, would contain certain downward bias associated with the exclusion of those gains, which must be kept in mind in the comparison between the British and the Spanish cases.

${ }^{11}$ See a survey of this type of analysis in Oum, Waters II and Yu, "Survey".
} 
If the firm is assumed not to minimize cost with respect to all inputs but only to a subset of variable factors, conditional on the level of the remaining (quasi-fixed) inputs, then the total cost function does not exist, and the variable cost function provides all the information required to infer the structure of production. In variable cost analysis, if quasifixed inputs are represented by network length $N$ (as is usual in those cases, such as the current research, in which the necessary information on each company's assets is incomplete) comparative statics analysis implies the following corrections for the formulae of technical change and returns to scale: ${ }^{12}$

Technical Change growth rate $=-\varepsilon_{c t} \cdot\left(1-\varepsilon_{c n}\right)^{-1}$

Returns to Scale $=\left(1-\varepsilon_{c n}\right) \cdot\left(\Sigma \varepsilon_{c y i}\right)^{-1}$

Returns to scale calculated as in expression 8 are most often denominated "returns to traffic density", since they reflect the relationship between inputs and outputs with the rail network held fixed. They constitute, therefore, an indicator of the opportunities to reduce average cost through increased use of the network, on the basis of potential economies in the use of train, labor and equipment. ${ }^{13}$ Returns to density are said to be increasing, constant or decreasing when their level is greater, equal of less than unity, respectively.

As may be readily inferred, the product of technical change (expression 7) and returns to density (expression 8), defined in terms of variable cost function elasticities, still yields expression 6 for the rate of growth of TFP. This section presents estimates of TFP growth and its two underlying factors (technical change and returns to density) for the Spanish railroads between 1858 and 1913, on the basis of a variable translog cost function, estimated for an unbalanced panel of 17 broad-gauge companies with a network longer than $100 \mathrm{~km}$ (accounting on average for 65 percent of the whole railroad network of the country). The specification of the function and the complete estimation results may be seen in Appendix 1.

The estimated coefficients of the variable cost function allow calculating partial elasticities of cost with respect to the explanatory variables at the sample mean, as well as estimates of the growth rate of technological change, returns to density and TFP growth, for two time spans: 1858-90 and 1891-1913. The distinction between these two periods

\footnotetext{
${ }^{12}$ A discussion on these aspects, as well as the mathematical developments that yield these formulae, may be seen in Caves, Christensen and Swanson, "Productivity Growth", pp. 995-996.

${ }^{13}$ On this subject see Keaton, "Economies", p. 212.
} 
responds to the incorporation of a trend dummy in the specification of the function, whose break point (1890) has been established on the basis of the Akaike information criterion. All estimates are displayed in Table 3. According to the table, the yearly rate of TFP growth in the Spanish railroad system was 0.53 percent between 1858 and 1890 and 2.28 percent between 1891 and 1913. These growth rates are within the range of those estimated for contemporary railroads. ${ }^{14}$ Compared with the British estimates for the period 18301910 (see Table 2 above), they indicate that TFP growth in the Spanish railroads was disappointingly slow until ca. 1890, but substantially accelerated since the last few years of the nineteenth century, reaching levels that were comparable, on average, to the British ones. As a result of that acceleration, the level of TFP in the railroad system in 1914 would have been 64 percent higher than in 1890, something which contrast with the constant criticisms that the service provided by the Spanish railroad companies received at the time, and with the deep "railroad pessimism" of many Spanish historians.

TABLE 3

TECHNICAL CHANGE, RETURNS TO DENSITY AND TFP GROWTH IN THE SPANISH RAILROADS (1858-1913)

\begin{tabular}{|l|c|c|}
\hline & $1858-1890$ & $1891-1913$ \\
\hline a) Elasticity of cost with respect to time $\left(\varepsilon_{\mathrm{ct}}\right)$ & -0.002 & -0.010 \\
\hline b) Elasticity of cost with respect to freight transport $\left(\varepsilon_{\mathrm{ctk}}\right)$ & 0.224 & 0.320 \\
\hline c) Elasticity of cost with respect to passenger transport $\left(\varepsilon_{\mathrm{cpk}}\right)$ & 0.188 & 0.119 \\
\hline d) Elasticity of cost with respect to network length $\left(\varepsilon_{\mathrm{cn}}\right)$ & 0.442 & 0.443 \\
\hline e) Technical change $\mathrm{growth} \mathrm{rate}\left[\varepsilon_{c t} \cdot\left(1-\varepsilon_{c n}\right)^{-1}\right]$ & 0.394 & 1.795 \\
\hline f) Returns to density $\left[\left(1-\varepsilon_{c n}\right) \cdot\left(\varepsilon_{c t k}+\varepsilon_{c p k}\right)^{-1}\right]$ & 1.352 & 1.271 \\
\hline g) TFP growth $\left[-\varepsilon_{c t} \cdot\left(\varepsilon_{c t k}+\varepsilon_{c p k}\right)^{-1}\right](e x f)$ & 0.534 & 2.278 \\
\hline
\end{tabular}

Source: see Appendix 1.

As has been pointed out, TFP growth may be considered as the product of the rate of growth of technical change and returns to traffic density. Regarding the latter, estimates in Table 3 indicate that Spanish railroads could benefit from substantial increasing returns to density during the whole period (at a level of 1.4/1.3). In other words, there were significant prospects of increasing productivity through the growth of output. Since the density of use of the Spanish railroad network grew more than three-fold between 1860 and

\footnotetext{
${ }^{14}$ See Oum, Waters II and Yu, "Survey", p. 29.
} 
the outbreak of the First World War, the railroad companies could indeed take advantage of that feature to increase their TFP throughout the period. ${ }^{15}$

The potential influence of returns to density on productivity was similar both before and after 1890, since neither the level of returns to density nor the growth rate of density itself experienced major changes between the two sub-periods under consideration. By contrast, the growth rate of technical change substantially increased after 1890, from 0.4 to 1.8 percent per year, and this change fully explains the acceleration in TFP growth from that year onwards. This increase is somehow surprising, since technology in the railroad sector did not suffer major alterations between the 1870 s and the general adoption of electric power. However, there were some opportunities for efficiency growth through the companies' agreements to share infrastructure or rolling stock, the use of steel instead of iron rails, and increases in locomotive power or in car capacity. ${ }^{16}$ As all these three aspects experienced certain progress in the Spanish railroad system during the period under consideration, efficiency could improve as time went by, allowing as a consequence the growth rate of TFP to increase substantially. ${ }^{17}$

\section{SPANISH RAILROADS TFP GROWTH: THE SOCIAL SAVING APPROACH}

The TFP gains provided by the Spanish railroad system may also be approached on the basis of the available social saving estimates. As has been pointed out, as far as the social savings represent the total direct gain in real income obtained from reducing resource costs in transportation, they will be equivalent to the total increase in TFP provided by the railroads to the economy. Accordingly, estimates of TFP gains based on the social savings will not only account for TFP growth in the railroad sector (as the figures that have been presented in the previous section) but also for the productivity effect of the shift from alternative transport modes to the railroads.

Actually, the equivalence between the social savings and TFP growth was already used by James Foreman-Peck to estimate the social savings of the English and Welsh railroads in 1890 on the basis of Hawke's figure for 1865 and an index of railroad TFP

\footnotetext{
${ }^{15}$ For the sources of information on the output of the Spanish railroads, see Appendix 1.

${ }^{16}$ See, for instance, Fishlow, "Productivity", pp. 634-42.

${ }^{17}$ For the increase in locomotive power, see Comín, Martín Aceña, Muñoz et al., 150 años, vol. 1, pp. 10206. For companies' mergers and take-overs, which explain the increasing shared utilization of infrastructure and rolling stock, see Tedde, "La expansión", pp. 277-79.
} 
growth. ${ }^{18}$ Here, this equivalence is used with a different objective, i.e. to estimate TFP gains on the basis of the social savings. This procedure may be described as follows. As has been indicated, the social savings are usually estimated as $\left(P_{A L T}-P_{F C}\right) x Q_{F C}$, where $P_{F C}$ and $P_{A L T}$ are, respectively, the price of railroad and counterfactual transport, and $Q_{F C}$ is the railroad transport output in the reference year. If the value of this expression is calculated for each kind of railroad traffic, the result would be an (upward biased) estimate of the additional equivalent variation consumer surplus provided by the railroads. The resulting figure, however, cannot be used as a direct measure of TFP growth, because it will only coincide with the real income gain provided by the railroads to the economy under the assumptions of a price-inelastic demand for transport, perfect competition in the transport industry and absence of idle resources. Therefore, in order to use the social savings to estimate TFP, they must be corrected to account for those assumptions. The result of those corrections will be an aggregate estimate of total income gain which, if expressed as a contribution to the annual growth rate, should equate the total railroad TFP contribution in expression (3). ${ }^{19}$ That yearly contribution may be divided by the ratio between railroad output and GDP to obtain an implicit TFP growth rate, which will include the productivity effects of the substitution among transport modes. The next paragraphs are intended to deal with these issues and to present, as a result, estimates of the railroad TFP contribution to growth between the beginning of the railroad era (1848) and the eve of the First World War.

In the case of low-speed freight transport (livestock excluded), all the necessary information to estimate the equivalent variation consumer surplus created by the Spanish railroads is provided by Gómez Mendoza in his social saving exercise. This author offers output and price figures for railroad and alternative transport means both for 1878 and 1912. ${ }^{20}$ Table 4 presents estimates of the (upward biased) additional consumer surplus of low-speed freight transport, which have been calculated on the basis of that information. ${ }^{21}$

\footnotetext{
${ }^{18}$ Foreman-Peck, "Railways", pp. 76-77.

${ }^{19}$ See Crafts, "Social Savings", p. 6.

${ }^{20}$ On these issues, see Gómez Mendoza, "Railways", pp. 50-64.

${ }^{21}$ Figures in Table 4 are upward biased because they do not allow for the re-routing of transport flows. These would probably have been relevant in the Spanish economy, because railroad routes might often be replaced by combinations of road transport and coastal navigation that were longer in distance, but cheaper than the direct road connection. For instance, before the railroad era, the wheat produced in Northern Castile was shipped to Catalonia not directly by road, but by boat from the Northern coast, circumventing the Peninsula, and this indirect route was likely to have been used again in a counterfactual economy without railroads; see, for instance, Garrabou and Sanz, "La agricultura española", p. 49. However, the lack of precise information
} 
TABLE 4

ADDITIONAL CONSUMER SURPLUS OF SPANISH RAILROAD LOW SPEED FREIGHT TRANSPORT $(\varepsilon=0)$

\begin{tabular}{|c|c|c|}
\hline & 1878 & 1912 \\
\hline \multicolumn{3}{|l|}{ Railroad economy: } \\
\hline (a) Railroad output (million ton-km) & 863.2 & $3,780.2$ \\
\hline (b) Railroad market fare (pesetas per ton-km) & 0.085 & 0.071 \\
\hline (c) Railroad output (million pesetas) (a $\mathrm{x}$ b) & 73.37 & 267.94 \\
\hline \multicolumn{3}{|l|}{ Counterfactual economy: } \\
\hline (d) Canal output (million ton-km) & 8 & \\
\hline (e) Canal rate (pesetas per ton-km) & 0.1198 & \\
\hline (f) Canal output (million pesetas) ( $\mathrm{d} \times \mathrm{e}$ ) & 0.96 & \\
\hline (g) Coastal navigation output (million ton-km) & 68.4 & 475 \\
\hline (h) Coastal navigation rate (pesetas per ton-km) & 0.03489 & 0.03224 \\
\hline (i) Coastal output (million pesetas) $(\mathrm{g} \times \mathrm{h})$ & 2.39 & 15.31 \\
\hline (j) Road output (million ton-km) & 669 & 2,809 \\
\hline (k) Carting rate (pesetas per ton-km) & 0.6775 & 0.6700 \\
\hline (1) Road output (million pesetas) (j x k) & 453.25 & $1,882.03$ \\
\hline (m) Additional consumer surplus (million pesetas) $(f+i+l-c)$ & 383.29 & $1,629.40$ \\
\hline
\end{tabular}

Note: Railroad output does not coincide with the sum of output figures by alternative means, because these have been corrected in order to account for the circuitousness of the Spanish railroad system; see Gómez Mendoza, "Railways", pp. 70-71.

Sources: Gómez Mendoza, "Railways", pp. 56-71, except for 1878 output figures, which have been taken from Gómez Mendoza, "Spain”, p. 152, Transport charges have been expressed in pesetas of 1878 and 1912 by using Prados de la Escosura's GDP deflator, from Prados de la Escosura, El progreso.

These figures must be corrected by the elasticity of transport demand, in order to eliminate their upward bias. As in similar research for other countries, ${ }^{22}$ the following transport demand function has been estimated for the period 1861-1913:

$\ln Q=\alpha+\beta_{1} \ln P+\beta_{2} \ln G D P+\beta_{3} \ln N+\beta_{4}$ time

where $Q$ is the railroad freight output, $P$ is the average market price of railroad freight transport (expressed in constant pesetas of 1861) and $N$ is the size of the railroad network. The unit root test analysis of the variables that appear in the function is shown and discussed in Appendix 2, and the results of the OLS estimation of the function are displayed in Table 5. The estimation output is actually the error correction vector of a cointegration model, since the residuals of the equation appear to be stationary. The price coefficient indicates an elasticity of demand of -0.79 . According to this estimate, the "true"

on the origin and destination of the actual railroad flows prevents the estimation of the magnitude of the bias associated with this aspect and Gómez Mendoza provides some evidence that interseas coastal trade shipment would have played a minor role in a counterfactual economy without railways; see Gómez Mendoza, "Railways", p. 54.

${ }^{22}$ See, for example, Coatsworth, "Indispensable Railroads", p. 951, Summerhill, Order, p. 94, and Ramírez, "Los ferrocarriles", p. 100. 
unbiased value of the additional consumer surplus provided by railroad low-speed freight transport was 163.68 million pesetas in 1878 (i.e. 43 percent of the upward biased estimate in Table 4) and 649.29 million pesetas in 1912 (i.e. 40 percent of the upward biased estimate). ${ }^{23}$

TABLE 5

(BROAD-GAUGE) RAILROAD FREIGHT TRANSPORT DEMAND FUNCTION (1861-1913)

\begin{tabular}{|l|c|}
\hline$N$ & 53 \\
\hline$A d j R^{2}$ & 0.99 \\
\hline$D W$ & 1.55 \\
\hline$\alpha$ & $\begin{array}{c}-3.24 * * \\
(0.76)\end{array}$ \\
\hline$\beta_{1}$ & $\begin{array}{c}-0.79 * * \\
(0.11)\end{array}$ \\
\hline$\beta_{2}$ & $\begin{array}{c}0.78^{* *} \\
(0.17)\end{array}$ \\
\hline$\beta_{3}$ & $\begin{array}{c}0.58^{* *} \\
(0.07)\end{array}$ \\
\hline$\beta_{4}$ & $\begin{array}{c}0.02 * * \\
(0.003)\end{array}$ \\
\hline ADF (residuals) & $-5.70^{* *}$ \\
\hline
\end{tabular}

Sources: railroad output and market prices from Gómez Mendoza, "Railways", except for 1861-69, which have been estimated by dividing the total revenue of the broad gauge network (taken from Spain, Ministerio de Fomento, Memorias) by the average market prices of the main companies (calculated from Anes, "Las relaciones" and Gómez Mendoza, "Transportes y comunicaciones"). GDP deflator and GDP from Prados de la Escosura, El progreso. Network size from Cordero and Menéndez, "El sistema".

A similar estimation may be carried out in the case of passenger traffic. Gómez Mendoza's social saving figures did not include passenger transport, because he considered it as a completely new commodity which, for the most part, would never have taken place without the advent of the railroads. ${ }^{24}$ However, subsequent research by the same author has shown that road passenger transport was highly developed by the beginning of the railroad era, being actually the object of the main technological improvements that took place in the road transport sector before $1850 .^{25}$ Santos Madrazo has estimated the custom of the Spanish stagecoach companies by that date in 825,000 passengers. ${ }^{26}$ Although this is a much lower number than the 7.5 million people that were transported by the railroads

\footnotetext{
${ }^{23}$ The ratio between the biased and unbiased estimates of additional consumer surplus is given by $\left[\left(\phi^{1+\varepsilon}\right.\right.$ $1) /(1+\varepsilon)(\phi-1)]$, where $\varepsilon$ is the elasticity of transport demand and $\phi$ is the ratio between counterfactual and railroad transport prices; see Fogel, "Notes", pp. 10-11.

${ }^{24}$ Gómez Mendoza, "Railways", p. 26.

${ }^{25}$ Gómez Mendoza, "Transportes", p. 477.
} 
already in $1861,{ }^{27}$ it also indicates that passenger transport was not a completely new commodity, at least in the case of the wealthiest social groups. As a consequence, and following the example of research on Mexico and Brazil, here it has been assumed that, in a hypothetical counterfactual economy without railroads, first and second class travelers would have used coach transport to make their journeys, whereas third class travelers would have walked instead. ${ }^{28}$ This is equivalent to assume only third-class railroad transport to be a completely new good.

Table 6 presents an estimate of the (upward biased) additional consumer surplus created by Spanish first and second-class passenger railroad transport in 1878 and 1912, which includes both the savings in transport unit costs and the working time saved thanks to higher speed. I have assumed first and second class travelers to be among the highestincome social groups, and have valued their travel time at twice the hourly wage of skilled industrial workers. ${ }^{29}$ It has also been considered, as in research for Mexico, Brazil or Russia, that only about half of the time savings were savings in working time and must therefore be included in the estimation of the additional consumer surplus for passenger transport. $^{30}$

\footnotetext{
${ }^{26}$ Madrazo, El sistema, p. 534.

${ }^{27}$ Figure coming from Spain, Ministerio de Fomento, Memoria(s).

${ }^{28}$ See Coatsworth, "Indispensable railroads", pp. 943-44, and Summerhill, Order, pp. 112-113.

${ }^{29}$ A similar procedure is followed by Summerhill, Order, p. 113.

${ }^{30}$ See Summerhill, Order, pp. 116-122, Metzer, Some Economic Aspects, pp. 60-62, and Coatsworth, "Indispensable Railroads", p. 945. There is, however, a great deal of uncertainty on the reasons for journeys in Spanish passenger transport.
} 
TABLE 6

ADDITIONAL CONSUMER SURPLUS OF SPANISH RAILROAD FIRST AND SECOND CLASS PASSENGER TRANSPORT $(\varepsilon=0)$

\begin{tabular}{|c|c|c|}
\hline & 1878 & 1912 \\
\hline (a) Passenger-km (million) & 203.18 & 564.71 \\
\hline (b) Rail rate (ptas/passenger-km) & 0.089 & 0.067 \\
\hline (c) Rail output (a x b) (million ptas) & 20.486 & 37.836 \\
\hline (d) Unit value of working travel time (ptas/hour) & 0.76 & 0.94 \\
\hline $\begin{array}{l}\text { (e) Working travel time by rail ( } 50 \text { per cent of a at } 34.4 / 45 \\
\text { km per hour) (million hours) }\end{array}$ & 2.953 & 6.275 \\
\hline $\begin{array}{l}\text { (f) Value of the working travel time by rail ( } \mathrm{d} x \text { e) (million } \\
\text { ptas) }\end{array}$ & 2.244 & 5.899 \\
\hline (g) Stagecoach rate (ptas/passenger-km) & 0.183 & 0.181 \\
\hline (h) Stagecoach output $(\mathrm{a} \times \mathrm{g} \times 0.85)^{\mathrm{a}}$ (million ptas) & 31.605 & 86.881 \\
\hline $\begin{array}{l}\text { (i) Working travel time by stagecoach ( } 50 \text { per cent of a } \mathrm{x} \\
0.85 \text { at } 7 \mathrm{~km} \text { per hour) }{ }^{\mathrm{a}} \text { (million hours) }\end{array}$ & 12.383 & 34.286 \\
\hline $\begin{array}{l}\text { (j) Value of the working travel time by stagecoach ( } \mathrm{d} \text { x i) } \\
\text { (million ptas) }\end{array}$ & 9.411 & 32.229 \\
\hline (k) Saving on transport costs (h-c) (million ptas) & 11.119 & 49.045 \\
\hline (1) Saving on travel time (j-f) (million ptas) & 7.167 & 26.330 \\
\hline$(m)$ Total savings $(k+l)($ million ptas $)$ & 18.286 & 75.375 \\
\hline
\end{tabular}

Note: (a) The 0.85 coefficient is intended to correct road output for the road network being less circuitous than the railroads (see Table 4).

Sources: Railroad output figures are the result of dividing the total railroad passenger revenues, from Spain, Ministerio de Fomento, Memorias, various dates, by the railroad rate. An average market rate of the two main companies (Norte and MZA) has been estimated from Anes, "Relaciones", pp. 487-91, and Compañía de los Ferrocarriles de Madrid a Zaragoza y a Alicante, Memoria(s), and first and second class rates have been distinguished from third class according to the MZA ratio between first and second class rate and average rate, taken from Compañía de los Ferrocarriles de Madrid a Zaragoza y a Alicante, Memoria(s). For stagecoach rate and speed, Madrazo, El sistema, pp. 552-60. The stagecoach rate has been expressed in pesetas of 1878 and 1912 by using Prados de la Escosura's GDP deflator, in El progreso. The unit value of working time is calculated as indicated in the text, from wage information in Camps, La formación, pp. 20415, which, for 1912, is consistent with the official national data published by the Instituto de Reformas Sociales. For railroad speed, Cordero and Menéndez, "El sistema ferroviario", pp. 307 and 335.

As in the case of freight, figures in Table 6 must be corrected for the price-elasticity of demand. This is difficult to estimate in the Spanish case, given the lack of information about the distribution of passenger transport between classes for a large part of the period under study. Research for other countries has assumed an elasticity of -1 for transport demand, and this figure is consistent with the information available for one of the largest Spanish companies $(M Z A) .{ }^{31}$ It has therefore been accepted here to correct the estimates of

\footnotetext{
${ }^{31}$ For the US, Boyd and Walton, "Social Savings", pp. 247-250, and, for Russia, Metzer, Some Economic Aspects, p. 73. A preliminary time-series estimation of first and second-class passenger transport demand elasticity for the company MZA in 1883-1912 offers a result of -0.82. The details of this estimation are available upon request.
} 
first and second class passenger transport additional consumer surplus. According to this correction, the "true" unbiased value of this additional consumer surplus was 13.42 million pesetas in 1878 (i.e. 73 percent of the upward biased estimate in Table 6) and 43.82 million pesetas in 1912 (i.e. 58 percent of the upward biased estimate).

Table 7 presents the additional consumer surplus associated with third-class passenger transport under the assumption of a completely inelastic demand, on the basis of the same information as the first and second classes. The only difference is the valuation of time savings, which is based in this case on the hourly wage of skilled industrial workers. ${ }^{32}$ These estimates cannot be corrected in the same way as those for the first and second classes since, as has been indicated, third class passenger transport is considered here as a completely new good. Under this assumption, the standard way to correct these figures is setting demand elasticity at such a level that, at the time of the introduction of the new good (or, in other words, at the price of counterfactual transport at the beginning of the railroad era), the demand for it was equal to zero. ${ }^{33}$ As might be expected, the resulting "true" unbiased value of the additional consumer surplus provided by third class railroad passenger transport is very small: 1.49 million pesetas in 1878 and 6.71 million pesetas in 1912 (i.e. 2 percent of the upward biased estimates in both years).

\footnotetext{
${ }^{32}$ Summerhill, Order, p. 117, uses, for lower-class passengers, a combination of the wages of "farm workers" and "skilled manufacturing workers". Other authors use the wage of "railway workers" or "manufacturing workers", without specifying professional rank; see Coatsworth, "Indispensable Railroads", p. 945, and Boyd and Walton, "Social Savings", p. 245.

${ }^{33}$ See, for instance, Hausman, "Valuation".
} 
ADDITIONAL CONSUMER SURPLUS OF SPANISH RAILROAD THIRD CLASS PASSENGER TRANSPORT $(\varepsilon=0)$

\begin{tabular}{|c|c|c|}
\hline & 1878 & 1912 \\
\hline (a) Passenger-km (million) & 495.15 & $2,339.89$ \\
\hline (b) Rail rate (ptas/passenger-km) & 0.047 & 0.036 \\
\hline (c) Rail output ( $\mathrm{a} \times \mathrm{b}$ ) (million ptas) & 23.272 & 84.236 \\
\hline (d) Unit value of working travel time (ptas/hour) & 0.38 & 0.47 \\
\hline $\begin{array}{l}\text { (e) Working travel time by rail ( } 50 \text { per cent of a at } 34.4 / 45 \\
\text { km per hour) (million hours) }\end{array}$ & 7.197 & 25.999 \\
\hline $\begin{array}{l}\text { (f) Value of the working travel time by rail ( } \mathrm{d} x \mathrm{e}) \text { (million } \\
\text { ptas) }\end{array}$ & 2.735 & 12.220 \\
\hline (g) Stagecoach rate (ptas/passenger-km) & 0.183 & 0.181 \\
\hline (h) Stagecoach output $(\mathrm{a} \times \mathrm{g} \times 0.85)^{\mathrm{a}}$ (million ptas) & 77.021 & 359.99 \\
\hline 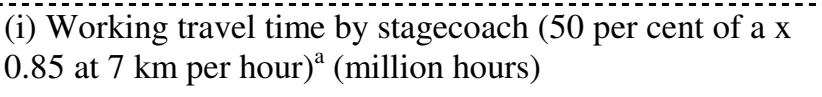 & 41.609 & 142.065 \\
\hline $\begin{array}{l}\text { (j) Value of the working travel time by stagecoach ( } \mathrm{x} \text { i) } \\
\text { (million ptas) }\end{array}$ & 15.811 & 66.77 \\
\hline (k) Saving on transport costs (h-c) (million ptas) & 53.749 & 275.754 \\
\hline (1) Saving on travel time (j-f) (million ptas) & 13.076 & 54.55 \\
\hline (m) Total savings $(k+l)$ (million ptas) & 66.825 & 330.304 \\
\hline
\end{tabular}

Note and sources: see Table 6.

Other sorts of freight transport (essentially high-speed freight) cannot be analyzed in the same way, because neither the official statistics nor the companies' accounts provide enough information to estimate output or market prices for the whole network. These traffic categories accounted for a non-negligible share of the total revenues of the railroad companies (7.6 percent in 1878 and 10.3 percent in 1912) and, therefore, their absence introduces certain downward bias in the global additional consumer surplus estimates. This bias, however, is probably small. Since, as in the case of third class passenger transport, most of that traffic might be considered as a completely new commodity, its contribution to the additional consumer surplus may be expected to be rather low.

Once the assumption of a price-inelastic transport demand has been removed, the additional consumer surplus figures must also be corrected to account for the presence of idle resources in the economy and the lack of competition in the railroad industry. Regarding the first issue, Gómez Mendoza provided alternative estimates of the railroad social saving for freight in 1878 that took into account the presence in the Spanish economy of a pool of underemployed peasants, which could have provided road transport 
services in the absence of the railroad system. In those estimates, the opportunity cost of road transport in the counterfactual economy is much lower than the actual market price ( 0.082 pesetas of 1878 per ton-km). The replacement of $P_{A L T}$ by that opportunity cost for two fifths of all freight transported by road in the counterfactual economy (i.e. for freight transported during the off-peak months of the agricultural working year) decreases the (unbiased) additional consumer surplus for low-speed freight transport by 24.37 percent in 1878 and 21.61 percent in $1912 .^{34}$

Secondly, in the estimation of the total resource savings provided by the railroads, it is necessary to account for the lack of competition in the railroad industry or, in other words, for the presence of supernormal profits in the sector. ${ }^{35}$ These may be calculated as the difference between total revenues and total expenses, including all capital costs (i.e. amortization and the opportunity cost of the capital invested in the system). Railroad supernormal profits defined in this way may be positive or negative and, in fact, negative "profits" seem to have been rather frequent in the Spanish railroad companies during the period of analysis, as has been often stressed by the historiography. ${ }^{36}$

Table 8 presents a calculation of the level of "supernormal profits" in the Spanish railroad industry in 1878 and 1912. For 1878, it confirms the impression of the sector's highly unfavorable financial situation during the first decades of the railroad era whereas, in the case of 1912, it reflects the effects of increasing efficiency and use of the network, which finally allowed the system to obtain positive supernormal returns in the eve of First World War. Figures in Table 8 are combined in Table 9 with the previous outcomes of the estimation of additional consumer surplus for different kinds of traffic. The sum of all these figures may be considered as a measure of the entire direct real income gain due to the railroads, which are expressed as a contribution to the annual rate of economic growth in the last row of the table.

\footnotetext{
${ }^{34}$ For the estimation of the opportunity cost figure and the two-fifths parameter, see Gómez Mendoza, "Railways", pp. 80-90.

${ }^{35}$ See McClelland, "Social Rates of Return", and Crafts "Social Savings", p. 7, footnote 2.

${ }^{36}$ See, for instante, Tortella, "Introducción”, p. 250; Comín, Martín Aceña, Muñoz et al., 150 años, Vol. 1, p. 144, or Keefer, "Protection", pp. 174-75.
} 
TABLE 8

“SUPERNORMAL PROFITS” IN THE SPANISH RAILROAD INDUSTRY IN 1878

AND 1912 (million pesetas)

\begin{tabular}{|l|c|c|}
\hline & 1878 & 1912 \\
\hline a) Total revenue & 132.346 & 400.205 \\
\hline b) Operating expenses & 60.045 & 191.765 \\
\hline c) Capital costs & 86.960 & 165.829 \\
\hline d) "Supernormal profits" (a-b-c) & -14.659 & 42.611 \\
\hline
\end{tabular}

Sources: total revenue and operation expenses, from Spain, Ministerio de Fomento, Memoria; capital costs are calculated on the basis of the railroad infrastructure stock estimation in Herranz-Loncán, "Spanish Infrastructure Stock", which has been increased by the value of land and rolling stock and has been applied a 6 percent opportunity cost (coming from Pascual, Los caminos, pp. 243-269 and 348) and the amortization rates that result from the average useful lives assumed in Herranz-Loncán's stock estimation.

TABLE 9

DIRECT REAL INCOME GAIN DUE TO THE RAILROADS IN 1878 AND 1912 (million pesetas of each year)

\begin{tabular}{|l|c|c|}
\hline & 1878 & 1912 \\
\hline $\begin{array}{l}\text { a) Low-speed freight transport additional consumer surplus (corrected for the presence } \\
\text { of idle resources) }\end{array}$ & 123.79 & 498.09 \\
\hline b) First and second-class passenger transport additional consumer surplus & 13.42 & 43.82 \\
\hline c) Third-class passenger transport additional consumer surplus & 1.49 & 6.71 \\
\hline d) Correction for the presence of supernormal profits & -14.66 & 42.61 \\
\hline Total $(a+b+c+d)$ & 124.04 & 591.23 \\
\hline As a \% of GDP & 1.42 & 4.60 \\
\hline As a contribution to the yearly growth rate since 1848 (\%) & 0.045 & 0.069 \\
\hline
\end{tabular}

Sources: see the text.

\section{THE CONTRIBUTION OF RAILROADS TO SPANISH ECONOMIC GROWTH}

Table 10 reports the contribution of railroads to Spanish economic growth, as results from the different TFP estimates that have been presented in the previous sections. Rows (a) to (c) display the railroad capital deepening contribution to growth in different periods, which is based on the most recent estimates of Spanish railroad capital stock. Rows (d) to (f), in turn, present the TFP growth contribution. In the first two columns, the TFP growth rates that were obtained from the estimation of the railroad cost function are included in row (d) and multiplied by the share of railroad output within GDP, in order to get figures of total TFP contribution. In the last two columns, the global TFP contribution that was estimated in the previous section on the basis of the social savings is included in row (f) and divided by the railroad output share to obtain an implicit TFP growth rate (row d), which includes the productivity effects of the substitution among transport modes. 
TABLE 10

RAILROADS' CONTRIBUTION TO GROWTH IN SPAIN, 1850-1913

\begin{tabular}{|c|c|c|c|c|}
\hline & $\begin{array}{c}\text { (1858-1890) } \\
\text { Cost function } \\
\text { approach }\end{array}$ & $\begin{array}{c}\text { (1891-1913) } \\
\text { Cost function } \\
\text { approach }\end{array}$ & $\begin{array}{c}\text { (1850-1878) } \\
\text { Social saving } \\
\text { approach }\end{array}$ & $\begin{array}{c}\text { (1850-1912) } \\
\text { Social saving } \\
\text { approach }\end{array}$ \\
\hline a) Railroad capital stock growth per capita & 7.43 & -0.11 & 11.33 & 4.70 \\
\hline b) Railroad profits share in national income & 0.73 & 1.35 & 0.42 & 0.86 \\
\hline c) Railroad capital contribution $(a \times b)$ & 0.054 & -0.001 & 0.048 & 0.040 \\
\hline d) Railroad TFP growth & 0.53 & 2.28 & 3.72 & 3.65 \\
\hline e) Railroad share in national output & 1.43 & 2.56 & 1.21 & 1.89 \\
\hline f) Railroad TFP contribution $(d x e)$ & 0.008 & 0.058 & 0.045 & 0.069 \\
\hline g) TFP Spillovers & - & - & - & - \\
\hline $\begin{array}{l}\text { h) Total railroad contribution }(c+f+g) \\
\text { (as \% of GDP per capita growth) }\end{array}$ & $\begin{array}{c}0.062 \\
5.00\end{array}$ & $\begin{array}{c}0.057 \\
6.12 \\
\end{array}$ & $\begin{array}{c}0.093 \\
7.51 \\
\end{array}$ & $\begin{array}{l}0.109 \\
11.00\end{array}$ \\
\hline
\end{tabular}

Note: The reference periods of the third and fourth columns start in 1850 (and not in 1848, as in Table 9) due to the absence of GDP estimates for 1848-49.

Sources: Growth of railroad capital stock from Herranz-Loncán, "Spanish Infrastructure Stock"; income (output) share is the average ratio between net (total) railroad revenues, from Spain, Ministerio de Fomento, Memoria, and nominal GDP from Prados de la Escosura, El progreso; TFP growth (row d) in the first two columns, from Table 3; TFP contribution (row f) in the last two columns, from Table 9; GDP per capita growth from Prados de la Escosura, El progreso.

Although the periods that are distinguished in the table are not strictly comparable with those considered by Crafts in his analysis of the British case (Table 2), it is possible to identify two features that the Spanish railroad system shared with the British one. Firstly, in both countries the growth rates of the railroad capital stock per person (row a) decreased as time went by and as the construction of the network gradually arrived to its virtual completion. The railroad stock per capita grew at extremely high rates during the first few years of the railroad era in both cases (22.8 percent in Britain in 1830-50, and 22 percent in Spain in 1850-66) and slowed down thereafter to much lower levels. The decrease was even more marked in Spain than in Britain, since the limited growth of the Spanish railroad network after the 1890s resulted in a negative rate in per capita terms since 1897. As a consequence of this evolution of the capital stock, during the first years of the railroad era most of the growth contribution of the railroad system was associated in both countries to capital deepening effects, whereas, as time went by and the growth of the railroad capital stock tended to stagnate, these effects became negligible and the TFP contribution gained increasing relevance.

Secondly, Tables 2 and 10 show that the participation of the railroad sector within the economy (rows b and e) increased steeply in both countries as time went by. In the Spanish case, for instance, the share of the railroads within national income increased 
eleven-fold between 1859 and 1912, and the importance of the sector within gross output experienced an eight-fold growth during the same period.

Regarding the growth rates of TFP (row d), similarities between both countries are less patent. In Britain, this variable showed an inverted-U pattern, reaching its maximum (3.5 percent per year) during the period 1850-70 and staying at much lower levels both in 1830-50 (1.9 percent) and in 1870-1910 (1 percent). In the Spanish case, if only productivity improvements within the railroad sector are considered, the growth rate of TFP appears to have been extremely slow until 1890 (0.5 percent), and to have accelerated substantially thereafter up to a level of 2.3 percent per year. By contrast, if the productivity gains that resulted from the substitution of the railroads for alternative transport means are also included in the estimation, the Spanish implicit growth rate of TFP (3.7 percent) appears to have been higher than the British maximum rate during the whole period under study. In addition, the comparison between this rate and those coming from the Spanish railroad cost function would imply that, before 1890, most railroad productivity gains were the result of the substitution among transport modes whereas, after that year, more than 50 percent of the TFP contribution came instead from efficiency improvements within the railroad system and from increasing density of use of the network.

The last two rows of Table 10 present estimates of the whole direct contribution of railroads to Spanish economic growth between the mid nineteenth century and the First World War. According to those figures, if the shift from alternative transport modes to the railroads is not considered, the direct economic impact of railroads amounted to 0.06 percentage points of growth per year (or, in relative terms, 5.0 to 6.1 percent of Spanish income per capita growth). By contrast, if the effects of the substitution among different transport modes are included, the global contribution was 0.11 percentage points per year (or 11 percent of income per capita growth). Although these are significant contributions for a single sector, they are not higher than the British equivalent figure, which amounted, on average, to 0.14 percentage points per year between 1830 and 1910 (or 12 percent of income per capita growth). ${ }^{37}$ In other words, the impact of railroads on economic growth through direct reduction in transport costs was not higher in Spain than in the UK, despite

\footnotetext{
${ }^{37}$ See Table 2. Actually, the Spanish disadvantage would appear even larger if the (small) TFP gains associated to the substitution of the British railroads for alternative transport modes were also accounted for in the British estimates (see above, footnote 10).
} 
the generally accepted idea that railroads were more vital in poor countries with fewer opportunities for water transport.

Figures in Tables 2 and 10 clearly show that the Spanish disadvantage was not the outcome of a slower growth rate of the capital stock or a stagnant TFP. On the contrary, the growth of railroad capital was to some extent comparable among both countries, and the growth rate of TFP seems to have been higher in Spain than in Britain. The main reason for the Spanish disadvantage was the fact that, at similar capital stock and TFP growth rates, the shares of the Spanish railroads within national income (row b) and output (row e) was always lower than the British one. Therefore, the potential benefits coming from the huge cost difference between the railroads and the alternative transport means were overcome in Spain by the minor role played by railroad transport in the economy. In sum, the direct contribution of the railroads to economic growth was not higher in Spain, whose geography put serious constraints on the development of water transportation, than in Britain, which could use it extensively before the advent of the railroads. To some extent, this result is in conflict with the general considerations of the traditional social saving literature, and might be explained by the fact that a large share of the much less developed Spanish economy remained largely unaffected by the railroad system for a long time, a situation that could probably be also found in other peripheral economies (such as Mexico, Brazil and Argentina) which had both low prospects to resort to cheap water transport and relatively low levels of development during the railroad era.

Finally, however, it is necessary to recall that growth accounting figures in Tables 2 and 10 exclude TFP spillovers, due to the difficulty to quantify them. The relevance of TFP spillovers from the railroads is a non negligible potential source of downward biases in growth accounting estimates, but the extent to which their inclusion might reduce the distance between the growth contribution of the Spanish and British railroads remains mere conjecture. In this context, within a future research agenda on the economic role of railroads, the importance of TFP spillovers from the railroad system must be considered as one of the most crucial aspects to analyze. 


\section{CONCLUSIONS}

This paper has provided growth accounting estimates of the contribution of railroads to Spanish economic growth, offering new insights on the long debated topic of the role of railroads in Spain's industrialization. Spain has usually been included among those countries where the railroads were expected to exert a higher potential impact, due to the lack of an extensive water transport system by the beginning of the railroad era. That hypothesis was reinforced by the outcomes of the early social saving literature, but received strong criticisms by some historians, due to the low density of use and the bad financial situation of the Spanish railroad companies. In that context, growth accounting has provided a more complete and comparable assessment of the growth contribution of the Spanish railroads than the traditional social savings estimates.

The analysis carried out in the paper shows that the TFP gains associated to the Spanish railroads were substantial before 1914, both through the shift from alternative transport means to the railroads and (especially since the last few years of the nineteenth century) through productivity improvements within the railroad system itself. However, in spite of those gains, the total direct impact of the Spanish railroads only accounted for 11 percent of income per capita growth, a percentage that was not higher, on average, than those estimated for the UK by Crafts. The main reason for this unexpected finding is the low importance of railroad transport within Spanish GDP, which prevented the resource savings provided by the substitution of the railroads for traditional overland transport, as well as the productivity gains that took place up to 1914, from having a more substantial impact on income per capita levels. In sum, the traditional hypothesis that the countries that gained most from the railroads were those where the share of freight taken off the roads and onto the railroad networks was higher, needs to be qualified on the basis of the different role that the railroads performed in each economy.

\section{APPENDIX 1}

\section{SPANISH RAILROAD COST FUNCTION (1858-1913)}

In order to estimate TFP growth in the Spanish railroad sector, I write the following generalized translog variable cost function: 


$$
\begin{aligned}
& \ln C V=\alpha_{0}+\sum_{i=1}^{m} \alpha_{i} \ln Y_{i}+\sum_{i=1}^{n} \beta_{i} \ln W_{i}+\beta_{n} \ln N+\theta_{t} T+\varphi_{d} D T+1 / 2 \sum_{i=1}^{m} \sum_{j=1}^{m} \delta_{i j} \ln Y_{i} \ln Y_{j}+ \\
& +1 / 2 \sum_{i=1}^{n} \sum_{j=1}^{n} \gamma_{i j} \ln W_{i} \ln W_{j}+1 / 2 \gamma_{n n}(\ln N)^{2}+1 / 2 \theta_{t t} T^{2}+1 / 2 \varphi_{d d} D T^{2}+\sum_{i=1}^{m} \sum_{j=1}^{n} \rho_{i j} \ln Y_{i} \ln W_{j}+ \\
& +\sum_{i=1}^{m} \rho_{i n} \ln Y_{i} \ln N+\sum_{i=1}^{m} \alpha_{i t} \ln Y_{i} \cdot T+\sum_{i}^{m} \alpha_{i d} \ln Y_{i} D T+\sum_{i=1}^{n} \beta_{i n} \ln W_{i} \ln N+\sum_{i=1}^{n} \beta_{i t} \ln W_{i} \cdot T+ \\
& +\sum_{i}^{n} \beta_{i d} \ln W_{i} \cdot D T+\beta_{n t} \ln N \cdot T+\beta_{n d} \ln N \cdot D T+F
\end{aligned}
$$

where $Y_{i}$ represents different outputs (ton-km and passenger-km), $W_{i}$ represents prices of different inputs (labor, coal and iron), $N$ is the network length, $T$ is a time trend representing technological change, $D T$ is the product of the time trend and a dummy that takes the value 1 for all years before a given $t$, and $F$ is a set of individual firm dummies. The endogenous variable is each company's yearly variable cost. The model has been estimated for an unbalanced panel of 17 broad-gauge companies with a network longer than $100 \mathrm{~km}$, which are listed in Appendix Table 1. Given the large number of parameters to estimate (60 with two outputs and three inputs), larger actually than the number of time observations, it has been necessary to incorporate additional restrictions in order to obtain relatively better defined coefficients. On the basis of the significance of the individual coefficients and the outcomes of the Akaike criterion, all coefficients of the products of input prices among them and with other variables have been assumed to be zero, as well as the coefficients of the products of output variables and network length and the products of the time trend and the time trend dummies with all other variables. This has reduced the number of parameters to estimate to 31 . The Akaike criterion has also been used to set the trend dummy as equal to zero from 1891 onwards. 
APPENDIX TABLE 1

LIST OF FIRMS IN THE SAMPLE

\begin{tabular}{lc}
\hline Firm & Time period \\
\hline Alar del Rey-Santander (ARS) & $1867-1877$ \\
Almansa a Valencia y Tarragona (AVT) & $1869-1885 ; 1887-1890$ \\
Andaluces (A) & $1878-1913$ \\
Bobadilla-Algeciras (BA) & $1892-1912$ \\
Central de Aragón (CA) & $1903-1913$ \\
Granollers-San Juan de las Abadesas (GSJ) & $1881-1889$ \\
Lorca-Baza y Águilas (LBA) & $1895-1901 ; 1903-1913$ \\
Madrid a Cáceres y Portugal (MCP) & $1882-1913$ \\
Madrid a Zaragoza y Alicante (MZA) & $1858-1913$ \\
Medina del Campo-Zamora y Orense-Vigo (MZOV) & $1867-1913$ \\
Norte (N) & $1865-1913$ \\
Salamanca-Portugal (SP) & $1888-1890 ; 1892-1913$ \\
Sur (S) & $1899-1913$ \\
Sevilla a Jerez y Cádiz (SJC) & $1867-1875$ \\
Tudela-Bilbao (TB) & $1867-1877$ \\
Zafra-Huelva (ZH) & $1889-1913$ \\
Zaragoza a Pamplona y Barcelona (ZPB) & $1867-1876$ \\
\hline
\end{tabular}

The data used in the estimation come from the following sources: a) Variable cost, output and network length of each company from Anes, "Relaciones", pp. 508-09; Anuario, various dates; Cambó, Elementos, vol. 2, pp. 94-98; Compañía de los Ferrocarriles de Madrid a Zaragoza y Alicante (MZA), Memoria; Gómez Mendoza, “Transportes y comunicaciones”, pp. 293-94; Spain, Ministerio de Fomento, Memoria; and Spain, Ministerio de Obras Públicas, Plan General, vol. 4, pp. 12-65. Each company's output before 1897, when not available, has been estimated by assuming similar hauls to later periods. b) Factor prices come from Anes, "Relaciones", p. 450; Carreras, "La industria", pp. 216-26; Coll and Sudrià, El carbón; Compañía de los Caminos de Hierro del Norte de España, Compañía; and Reher and Ballesteros, "Precios".

Appendix Table 2 displays the outcomes of the estimation of the model. Estimates in the table are feasible generalized least squares, robust to the presence of autocorrelation and panel heteroskedasticity. 
APPENDIX TABLE 2

TRANSLOG COST FUNCTION OF SPANISH BROAD GAUGE RAILROADS (1858-

1913)

\begin{tabular}{|c|c|}
\hline$N$ & 406 \\
\hline Adj. $R^{2}$ & 0.997 \\
\hline$D W$ & 0.90 \\
\hline$\alpha_{\mathrm{TK}}$ & $\begin{array}{c}0.226 * * \\
(0.027)\end{array}$ \\
\hline$\alpha_{\mathrm{PK}}$ & $\begin{array}{l}0.121 * * \\
(0.033)\end{array}$ \\
\hline$\beta_{\mathrm{L}}$ & $\begin{array}{c}0.714 * * \\
(0.123)\end{array}$ \\
\hline$\beta_{\mathrm{C}}$ & $\begin{array}{l}0.174 * * \\
(0.035)\end{array}$ \\
\hline$\beta_{\text {I }}$ & $\begin{array}{c}0.092 * * \\
(0.031)\end{array}$ \\
\hline$\beta_{\mathrm{n}}$ & $\begin{array}{c}0.357 * * \\
(0.132)\end{array}$ \\
\hline$\theta_{\mathrm{t}}$ & $\begin{array}{c}-0.019 * * \\
(0.003)\end{array}$ \\
\hline$\varphi_{\mathrm{d}}$ & $\begin{array}{c}-0.017 * * \\
(0.003)\end{array}$ \\
\hline$\delta_{\text {TKTK }}$ & $\begin{array}{c}0.161 * * \\
(0.027)\end{array}$ \\
\hline$\delta_{\mathrm{PKPK}}$ & $\begin{array}{c}0.169 * * \\
(0.030)\end{array}$ \\
\hline$\delta_{\mathrm{TKPK}}$ & $\begin{array}{c}-0.156 * * \\
(0.028)\end{array}$ \\
\hline$\gamma_{\mathrm{nn}}$ & $\begin{array}{c}-0.014 \\
(0.017)\end{array}$ \\
\hline$\theta_{\mathrm{tt}}$ & $\begin{array}{c}0.0006^{* *} * \\
(0.0001)\end{array}$ \\
\hline$\varphi_{\mathrm{dd}}$ & $\begin{array}{c}0.0013 * * \\
(0.0002)\end{array}$ \\
\hline \multicolumn{2}{|c|}{ Fixed effects: } \\
\hline ARS & 0,473 \\
\hline $\mathrm{N}$ & 0,380 \\
\hline ZPB & 0,306 \\
\hline MZA & 0,175 \\
\hline AVT & 0,148 \\
\hline $\mathrm{BA}$ & 0,107 \\
\hline $\mathrm{S}$ & 0,099 \\
\hline SJC & 0,067 \\
\hline $\mathrm{A}$ & 0,052 \\
\hline MCP & $-0,036$ \\
\hline $\mathrm{ZH}$ & $-0,144$ \\
\hline TB & $-0,180$ \\
\hline LBA & $-0,212$ \\
\hline MZOV & $-0,214$ \\
\hline GSJ & $-0,250$ \\
\hline SP & $-0,336$ \\
\hline $\mathrm{CA}$ & $-0,435$ \\
\hline
\end{tabular}

* Significant at the 5 percent level.

** Significant at the 1 percent level.

Notes: Standard errors in brackets. 


\section{APPENDIX 2 \\ TRANSPORT DEMAND FUNCTION (UNIT ROOT TESTS)}

The series included in the transport demand function (10) have been applied the Dickey-Fuller unit root test in order to know their level of integrability. The results of the test are shown in Appendix Table 3. All series appear to be I(1), with the exception of $\ln N$, for which the null of presence of a unit root tends to be rejected, although this result depends on the specification of the test. The ambiguity of this outcome result gives some support to the consideration of this variable as a "near-unit-root" process, which are often recommended to be treated as unit root processes, given the low power of the available tests (see, for instance, Granger, "What are we Learning about the Long Run?", pp. 309310, and Doornik, Hendry and Nielsen, "Inference", p. 536). This choice has been adopted here because it allows working with the series in levels and keeping all the information that they contain. In addition, it makes possible to obtain elasticity figures that are comparable to other countries' and may be used to correct the bias of figures in Table 4.

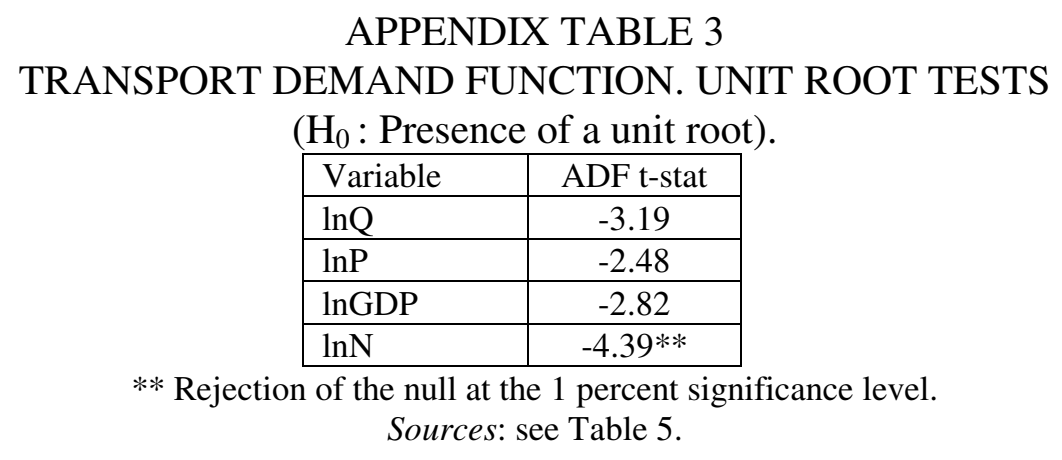

\section{REFERENCES}

Anes, Rafael. "Relaciones entre el ferrocarril y la economía española (1865-1935).” In Los ferrocarriles en España, 1844-1943, edited by Miguel Artola, vol. 2, 355-512. Madrid: Banco de España, 1978.

Anuario de Ferrocarriles de D. Enrique de la Torre, various dates.

Boyd, J. Hayden, and Gary M. Walton. "The Social Savings from Nineteenth-Century Rail Passenger Services." Explorations in Economic History 9, no. 3 (1972): 233-54.

Cambó, Francisco, ed. Elementos para el estudio del problema ferroviario en España. Madrid: Ministerio de Fomento, 1918-1922.

Camps, Enriqueta. La formación del mercado de trabajo industrial en la Cataluña del siglo XIX. Madrid: Ministerio de Trabajo y Seguridad Social, 1995. 
Caron, François. "France." In Railways and the Economic Growth of Western Europe, edited by Patrick O'Brien, 28-48. London: McMillan, 1983.

Carreras, Albert. "La industria." In Estadísticas Históricas de España, siglos XIX-XX, edited by Albert Carreras, 169-247. Madrid: Fundación Banco Exterior, 1989.

Caves, Douglas W., Laurits R. Christensen, and Joseph A. Swanson. "Productivity Growth, Scale Economies and Capacity Utilization in U.S. Railroads, 1955-74." American Economic Review 71, no. 5 (1981): 994-1002.

Coatsworth, John H. "Indispensable Railroads in a Backward Economy: The Case of Mexico.” This Journal 39, no. 4 (1979): 939-60.

Coll, Sebastián, and Sudrià, Carles. El carbón en España, 1770-1961. Una historia económica. Madrid: Turner, 1987.

Comín, Francisco, Pablo Martín Aceña, Miguel Muñoz et al. 150 Años de Historia de los Ferrocarriles Españoles. Madrid: Fundación de los Ferrocarriles Españoles, 1998.

Compañía de los Caminos de Hierro del Norte de España. Compañía de los Caminos de Hierro del Norte de España (1858-1939). Historia. Actuación. Concesiones. Ingresos. Gastos y balance. Madrid: Espasa Calpe, 1940.

Compañía de los Ferrocarriles de Madrid a Zaragoza y a Alicante (MZA). Memorias, various dates.

Cordero, Ramón, and Fernando Menéndez. "El sistema ferroviario español." In Los ferrocarriles en España, 1844-1943, edited by Miguel Artola, vol. 1, 161-338. Madrid: Banco de España, 1978.

Crafts, N.F.R. "Social Savings as a Measure of the Contribution of a New Technology to Economic Growth." LSE. Department of Economic History Working Paper No. 06/04, London, July 2004.

- "Steam as a General Purpose Technology: A Growth Accounting Perspective." Economic Journal 114 (2004): 338-351.

Doornik, Jurgen A., David F. Hendry, and Bent Nielsen. "Inference in Cointegrating Models: UK M1 Revisited.” Journal of Economic Surveys 12, no. 5 (1998): 533-572.

Fishlow, Albert. American Railroads and the Transformation of the Ante-bellum Economy. Cambridge, MA: Harvard University Press, 1965.

-. "Productivity and Technological Change in the Railroad Sector, 1840-1910." In Output, Employment and Productivity in the United States After 1800, NBER Studies in Income and Wealth, vol. 30, edited by Dorothy S. Brady, 583-646. New York: National Bureau of Economic Research, 1966.

Fogel, Robert W. Railroads and American Economic Growth: Essays in Econometric History. Baltimore: The John Hopkins Press, 1964. 
—. "Notes on the Social Saving Controversy." This Journal 39, no. 1 (1979): 1-54.

Foreman-Peck, James. "Railways and Late Victorian Economic Growth." In New Perspectives on the Late Victorian Economy, edited by James Foreman-Peck, 73-95. Cambridge: Cambridge University Press, 1991.

Garrabou, Ramon, and Jesús Sanz. "La agricultura española durante el siglo XIX: ¿inmovilismo o cambio?”. In Historia agraria de la España contemporánea. Vol. 2. Expansión y crisis (1850-1900), edited by Ramon Garrabou and Jesús Sanz, 7-191. Barcelona: Crítica, 1985.

Gómez Mendoza, Antonio. "Railways and Spanish Economic Growth in the Late 19h Century." Ph.D. diss., University of Oxford, 1981.

-. "Spain." In Railways and the Economic Growth of Western Europe, edited by Patrick O’Brien, 148-69. London: McMillan, 1983.

—. "Transportes y Comunicaciones." In Estadísticas Históricas de España, siglos XIX-XX, edited by Albert Carreras, 269-323. Madrid: Fundación Banco Exterior, 1989.

—. "Transportes." In Historia de España de Don Ramón Menéndez Pidal. Vol. XXXIII. Los fundamentos de la España liberal (1834-1900). La sociedad, la economía y las formas de vida, 465-515. Madrid: Espasa Calpe, 1997.

Granger, Clive W. J. "What are we Learning about the Long-Run?" Economic Journal 103 (1993): 307-317.

Hausman, Jerry A. "Valuation of New Goods under Perfect and Imperfect Competition." NBER Working Paper no. 4970, 1994.

Hawke, Gary R. Railways and Economic Growth in England and Wales. Oxford: Clarendon Press, 1970.

Herranz-Loncán, Alfonso. “The Spanish Infrastructure Stock, 1844-1935”. Research in Economic History 23 (2005): 85-129.

Jara-Díaz, Sergio R. "On the Relation Between Users' Benefits and the Economic Effects of Transportation Activities.” Journal of Regional Science 26, no. 2 (1986), 379-391.

Keaton, Mark H. "Economies of Density and Service Levels on U.S. Railroads: An Experimental Analysis." Logistics and Transportation Review 26, no. 3 (1990): 211-227.

Keefer, Philip. "Protection Against a Capricious State: French Investment and Spanish Railroads, 1845-1875.” This Journal 56, no. 1 (1996): 170-92.

Laffut, Michel. "Belgium." In Railways and the Economic Growth of Western Europe, edited by Patrick O’Brien, 203-26. London: McMillan, 1983.

Madrazo, Santos. El sistema de comunicaciones en España, 1750-1850. Madrid: Turner, 1984. 
McClelland, Peter D. "Social Rates of Return on American Railroads in the Nineteenth Century." Economic History Review 25, no. 3 (1972): 471-488.

Metzer, Jacob. Some Economic Aspects of Railroad Development in Tsarist Russia. New York: Arno Press, 1977.

- "Railroads and the Efficiency of Internal Markets: Some Conceptual and Practical Considerations." Economic Development and Cultural Change 33, no. 1 (1984): 61-70.

Mitchell, B.R. British Historical Statistics. Cambridge: Cambridge University Press, 1988.

Mulhall, Michael G. The progress of the world. London: Edward Stanford, 1880.

O'Brien, Patrick. "Transport and Economic Development in Europe, 1789-1914." In Railways and the Economic Growth of Western Europe, edited by Patrick O'Brien, 1-27. London: McMillan, 1983.

Oliner, Stephen D., and Sichel, Daniel E. "Information Technology and Productivity: Where Are We Now and Where Are We Going." Federal Reserve Bank of Atlanta Economic Review 87, no. 3 (2002): 15-44.

Oum, Tae Hoon, W.G. Waters II, and Chunyan Yu. "A Survey of Productivity and Efficiency Measurement in Rail Transport." Journal of Transport Economics and Policy 33, no. 1 (1999): 9-42.

Pascual, Pere. Los caminos de la era industrial. La construcción y financiación de la Red Ferroviaria Catalana (1843-1898). Barcelona: Edicions Universitat de Barcelona, 1999.

Prados de la Escosura, Leandro. Comercio exterior y crecimiento económico en España, 1821-1913. Madrid: Banco de España, 1982.

—. El progreso económico de España, 1850-2000. Madrid: Fundación BBVA, 2003.

Ramírez, María Teresa. "Los ferrocarriles y su impacto sobre la economía colombiana." Revista de Historia Económica 19, no. 1 (2001): 81-122.

Reher, David S., and Esmeralda Ballesteros. "Precios y salarios en Castilla la Nueva: la construcción de un índice de salarios reales, 1501-1991." Revista de Historia Económica 11, no. 1 (1993): 101-51.

Solomou, S.N., and Weale, M. "Balanced Estimates of UK GDP, 1870-1913." Explorations in Economic History 28 (1991): 54-63.

Spain, Ministerio de Fomento, Memoria(s), Anuario(s) and Estadística(s) de Obras Públicas, various dates.

Spain, Ministerio de Obras Públicas. Plan General de Obras Públicas. Madrid: Talleres Penitenciarios de Alcalá, 1940.

Summerhill, William. "Profit and Productivity on Argentine Railroads, 1857-1913". Los Angeles: Department of History, UCLA (mimeo). 
-. Order Against Progress. Government, Foreign Investment, and Railroads in Brazil, 1854-1913. Stanford: Stanford University Press, 2003.

Tedde, Pedro. "La expansión de las grandes compañías ferroviarias españolas: Norte, MZA y Andaluces." In La empresa en la historia de España, edited by Francisco Comín and Pablo Martín Aceña, 265-84. Madrid: Civitas, 1996.

Tortella, Gabriel. Los orígenes del capitalismo en España. Banca, industria y ferrocarriles en el siglo XIX. Barcelona: Tecnos, 1973.

—. "Introducción. La paradoja del ferrocarril español." In Siglo y medio del ferrocarril en España, 1848-1998. Economía, Industria y Sociedad, edited by Miguel Muñoz, Jesús Sanz and Javier Vidal, 249-53. Madrid: Fundación de los Ferrocarriles Españoles, 1999. 